\title{
Surgical treatment of subcostal incisional hernia with polypropylene mesh - analysis of late results
}

\section{Tratamento cirúrgico da hérnia incisional subcostal com tela de polipropileno - análise de resultados tardios}

\author{
Marco Antonio de Oliveira Peres, tCBC-SP1; Herberti Rosique Aguiar1; Nelson Adami Andreollo,tCBC-SP1
}

\author{
A B S S T R A C T
}

\begin{abstract}
Objective: To evaluate the results of subcostal incisional hernia repair using polypropylene mesh, the technical aspects of musculoaponeurotic reconstruction, routine fixation of supra-aponeurotic mesh and follow-up for five years. Methods: We conducted a retrospective study that assessed 24 patients undergoing subcostal incisional hernia repair with use of polypropylene mesh; 15 patients (62.5\%) were female; ages ranged from 33 to 82 , and $79.1 \%$ had comorbidities. Results: Early complications: three cases $(12.5 \%)$ of wound infection, three cases $(12.5 \%)$ of seroma, one case $(4.1 \%)$ of hematoma; and one case $(4.1 \%)$ of wound dehiscence. Late complications occurred in one case $(4.1 \%)$ of hernia recurrence attributed to technical failure in the fixation of the mesh and in one case $(4.1 \%)$ of chronic pain. There were no cases of exposure or rejection of the mesh. Conclusion: The subcostal incisional hernia, though not very relevant, requires adequate surgical treatment. Its surgical correction involves rebuilding the muscle-aponeurotic defect, supra-aponeurotic fixation of polypropylene mesh, with less complexity and lower rates of complications and recurrences.
\end{abstract}

Key words: Hernia. Hernia, ventral. Surgical procedures, operative. Polypropylenes. Outcome assessment (health care).

\section{INTRODUCTION}

T ransverse incisions in the upper abdomen have been described since the beginning of last century, with the first cases of cholecystectomy and hepatobiliopancreatic interventions ${ }^{1,2}$. The right subcostal incision was described by Kocher and received his name; he advocated an oblique incision, which followed the costal margin, providing good presentation of the biliary tract ${ }^{3}$. His routine standardization, gradually replacing right paramedian incision, was widespread in the Brazilian academia in the 80s, being applied in cholecystectomy and biliary tract approaches. Before long, the bilateral subcostal incision, known as the Chevron incision, became used as good access in some urological ${ }^{4}$, pancreatic and liver procedures and, more recently, in liver transplants ${ }^{5-8}$.

The subcostal incision is classified in the group of transverse incisions, bringing benefits such as good exposure of the upper floor of the abdominal cavity, the facility in closing the layers of the abdominal wall, and lower incidence of incisional hernia ${ }^{3}$. However, it has the drawback of sectioning muscle fibers, especially of the upper rectus abdominis and obliques, rendering greater technical difficulty during any correction of such hernias due to the proximity of the costal margin.
This work aimed to evaluate the clinical effects of subcostal incisional hernia repair, the technical aspects of musculo-aponeurotic reconstruction, routine fixation of polypropylene mesh and follow-up for five years.

\section{METHODS}

We reviewed medical records of 337 patients undergoing incisional hernia repair between April 2001 and August 2005 at the General Surgery Department of State Hospital of Sumaré. The medical records of 24 patients undergoing subcostal incisional hernia repair with polypropylene mesh were selected for this study. The following variables were evaluated: age, sex, associated diseases, location of the hernia, operation previous to the hernia, previous operation for correction of incisional hernia and time of appearance of the hernia.

The patients underwent the following preoperative tests: blood count, blood glucose, coagulation, serum electrolytes and renal function, electrocardiogram and chest $X$-rays, according to the service surgical-clinical protocol. Imaging tests were ordered at the presence of comorbidities, high degree of abdominal herniation and previous diseases. Computed tomography of the abdomen

1. Department of Surgery, Faculty of Medical Sciences, State University of Campinas - UNICAMP, Campinas / SP. 
was not considered mandatory; it was only requested by a history of malignancy or in patients with suspected associated abdominal diseases. All patients underwent preanesthetic evaluation and the risk scale established by ASA.

All patients underwent general intravenous and inhalational anesthesia with tracheal intubation and controlled mechanical ventilation.

Initially, incision was performed with resection of the prior subcostal scar (Figure 1). This was followed by dissection by plans to identify the upper and lower rectus abdominis stumps, with its anterior and posterior aponeurosis and the entire hernia sac. Since the hernia sac was opened often during dissection, adhesions were undone, followed by suture with absorbable 2-0 polyglactin. In all cases it was possible to repair the muscle-aponeurotic layer, not always without tension, with absorbable polydioxanone suture (PDS II), rapprochement of the edges by continuous non-anchored suture, reconstructing the abdominal wall (Figure 2). The $30 \times 30 \mathrm{~cm}$ (unilateral hernia) or $26 \times 36 \mathrm{~cm}$ (bilateral hernia) polypropylene mesh was fixated to the newly reconstituted anterior aponeurosis. The mesh was fixed in its entire length, with separate 2-0 polypropylene sutures (Figure 3). Pursuant to a previous protocol, the wound was routinely drained by vacuum. Next, we proceeded with the synthesis of the subcutaneous tissue in two planes with catgut or vicryl 3-0 3-0, and the skin with 4-0 nylon.

Antibiotic therapy was started two hours before surgery with cephalothin ( $2 \mathrm{~g}$ ) administered intravenously, followed by seven to ten days of oral cephalexin (500 mg every six hours). All patients used the belt strap elastic waist on the same night of the surgery.

We evaluated general, local, early and late complications. The first outpatient visit occurred between

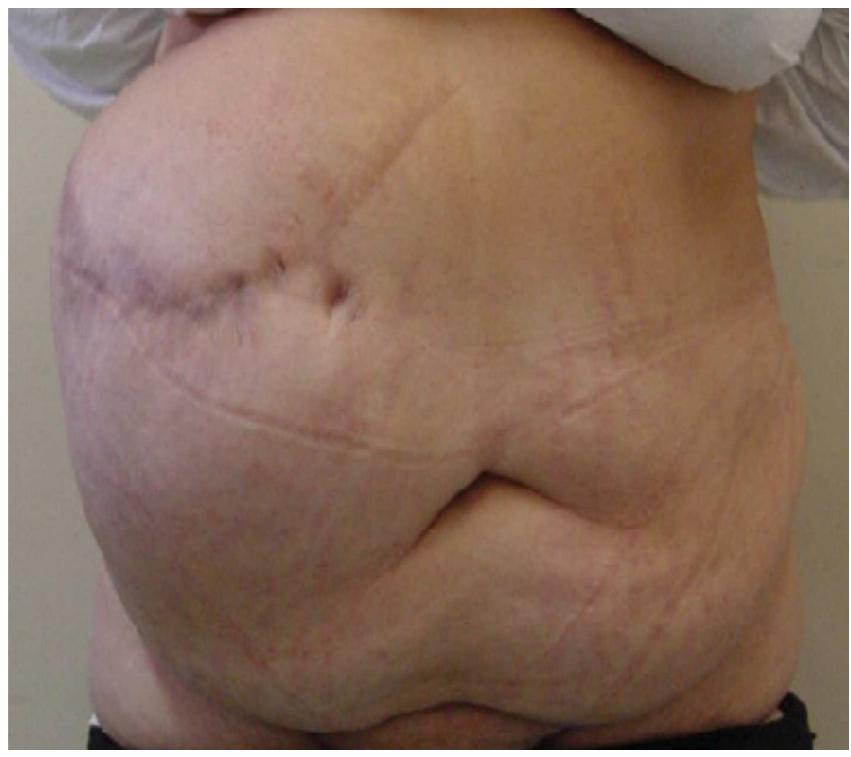

Figura 1 - Hérnia subcostal direita, com deformidade e eventração. the seventh and ninth day postoperatively. All patients were discharged with the vacuum drain, with guidance as to household debt control; the drains were withdrawn in the next two weeks, according to the aspect and expected debt reduction.

All cases were reevaluated in the second month, sixth month, first year and once a year until the fifth year postoperatively.

\section{RESULTS}

Twenty-four patients underwent incisional hernia repair, corresponding to $7,1 \%$ of incisional hernia repairs

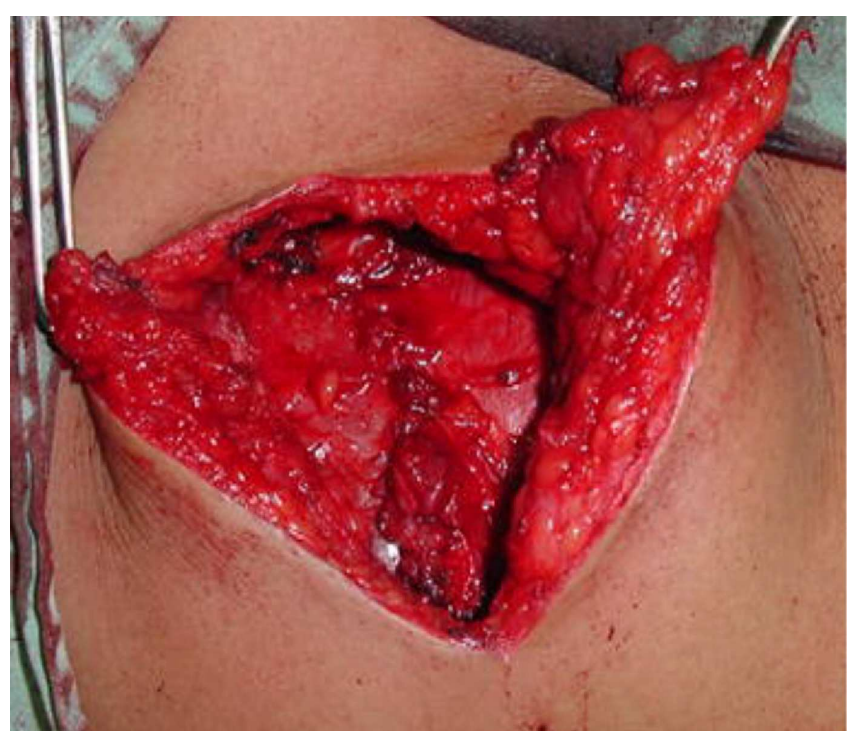

Figure 2 - Musculo-aponeurotic raphy by continuous suture of the hernia orifice.

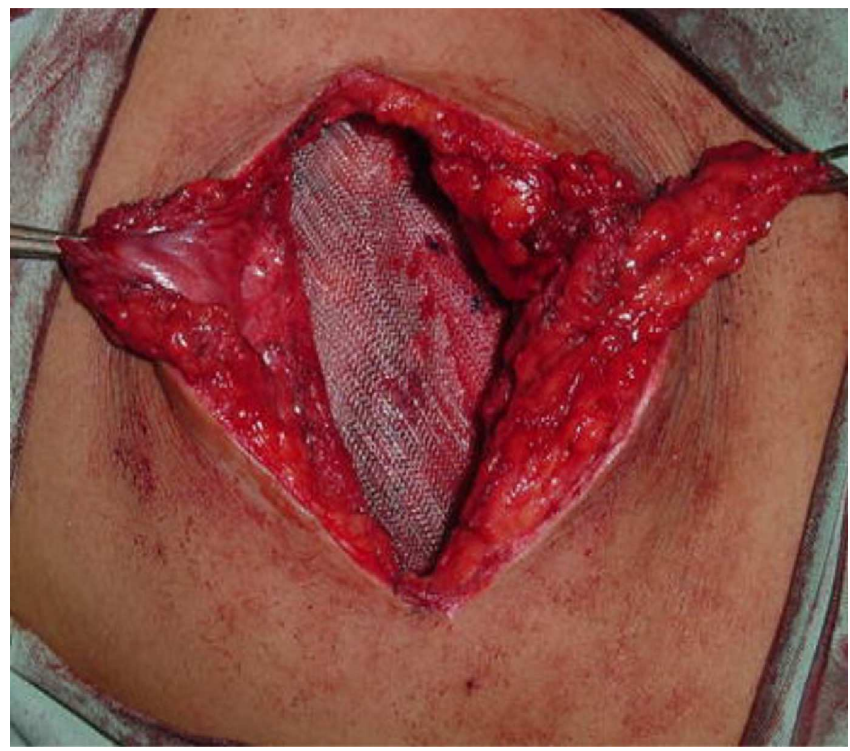

Figure 3 - Fixation of the polypropylene mesh on the newly reconstituted aponeurosis. 
performed; nine patients (37.5\%) were male and 15 $(62.5 \%)$ females, with ages ranging from 33 to 82 years, median age 49. Associated diseases were found in $19 \mathrm{ca}-$ ses $(79.1 \%)$, mainly hypertension, diabetes and obesity (Table 1). Regarding location, 23 hernias were right unilateral, one being subcostal bilateral. Three other cases $(12.5 \%)$ were not included in the review due to loss of follow-up.

As for the operation that generated the herniation, 19 cases (79.1\%) were cholecystectomies for cholelithiasis, one case (4.1\%) biliary-enteric bypass; and two $(8.2 \%)$ other procedures (Table 2 ). Of these, 22 $(91.8 \%)$ were operated for the first time for the correction of subcostal hernia, and two $(8.2 \%)$ had undergone previous hernia repair without prosthesis. The average time from onset of hernia ranged from six months to three years.

Regarding overall complications, there was only one case of small atelectasis of the right lung, associated with severe pain in the first two days, with favorable clinical resolution.

Early local complications were recorded: three cases $(12.5 \%)$ of wound infection, as infectious cellulitis, treated with local measures and changing antibiotics; three cases $(12.5 \%)$ of seroma, of easy outpatient control by needle punctures, one case $(4.1 \%)$ of hematoma treated conservatively, one case (4.1\%) of non-infectious wound dehiscence with resuture in the outpatient setting, preventing exposure of the mesh; and one case $(4.1 \%)$ of pain refractory to the usual oral analgesics for nearly six months.

As for late complications, there was one case (4.1\%) of hernia recurrence, attributed to technical failure in fixing the mesh, of small size, which did not adequately cover the linea alba. The patient was reoperated 14 months after, and a new polypropylene mesh was placed in the deffect. There were no cases of exposure or rejection of the mesh in this series. The average length of hospitalization ranged from three to five days.

\section{DISCUSSION}

Due to the implementation and enablement of new services for laparoscopic surgery, there is a downward trend in the number of conventional cholecystectomy ${ }^{9-11}$. In parallel, with the advent of transverse incisions, specifically in the subcostal complex procedures of the biliary tract, pancreas and liver, there has been an increase in the number of cases of subcostal incisional hernias ${ }^{12,13}$, mainly in jaundiced patients, in emergency operations and in contaminated or infected procedures.

Most literature reviews on incisional hernias only report data on the incidence or percentage of subcostal hernias, without describing details of the correction technique used for its treatment.
Table 1 - Associated diseases.

\begin{tabular}{llc}
\hline Associated Diseases & N & $\%$ \\
\hline Systemic hypertension (SH) & 4 & 16.6 \\
Obesity & 3 & 12.5 \\
SH / Obesity & 2 & 8.3 \\
Diabetes mellitus (DM) & 2 & 8.3 \\
SH / DM & 1 & 4.1 \\
DM / Alcoholism & 1 & 4.1 \\
DM / Tobacco & 1 & 4.1 \\
heart disease & 1 & 4.1 \\
Other associations & 4 & 16.6 \\
ASA I: & 5 cases $(20.9 \%)$ \\
ASA II: & 19 cases $(79.1 \%)$ \\
\hline
\end{tabular}

Table 2 - Types of operations that caused the herniation.

\begin{tabular}{lrc}
\hline Operations & N & $\%$ \\
\hline Cholecystectomy & 19 & 79.1 \\
Biliary-enteric bypass & 1 & 4.1 \\
Hepatic hemangioma & 1 & 4.1 \\
Peri-pancreatic abscess & 1 & 4.1 \\
Ureteropieloplastia & 1 & 4.1 \\
Resection of liver cyst & 1 & 4.1 \\
\hline
\end{tabular}

In this series the 24 patients with subcostal hernias were inserted in the treatment of 337 cases of all hernias recorded in a period of 52 months, corresponding to $7.1 \%$ of the total. The literature report subcostal hernia incidence between $4 \%$ and $20 \%$ 12,14-16. Regarding the technical choice for supra-aponeurotic fixation of the mesh, therefore in contact with the subcutaneous tissue, it was due to the greater ease of abdominal wall reconstruction in a single plane, not resecting the hernia sac, just internalizing it below the synthesis. The separation of the aponeurotic component above and below the rectus muscle, both in the upper and lower stump, is technically difficult, bleeding-prone, and does not allow a secure suture approximation of the edges in the technique of retromuscular mesh fixation. Hence our preference for the pre-aponeurotic placement of the mesh.

The polypropylene mesh has been used routinely by many surgeons in various incisional and inguinal hernias. It is shown to be safe and offers several advantages, such as ease of obtaining, easy handling, low cost and excellent tolerance, with no significant longterm complications ${ }^{16,17}$. Piardi et al. ${ }^{7}$ recommend that the polypropylene mesh is the first choice for the correction of incisional hernias after hepatic transplantation ${ }^{7}$.

The infection rate of $12.5 \%$ in this sample was acceptable compared to other publications ${ }^{18,19}$, consequent 
to the routine use of vacuum drain for no short time and antibiotic therapy with first-generation cephalosporin, due to its wide spectrum of action and easy delivery in our health care system.

A number of patients complained of postoperative pain in the first two to three months after the operation, in contrast to interventions in the midline, as in a case of this study. In rare cases, pain persists for six months or a year, which implies specific medications or treatment by infiltration.
We conclude that the subcostal incision, whether right unilateral or bilateral, maintains its importance in elective or emergency operations of the biliary tree, pancreas and liver. The presence of subcostal hernia, despite being very relevant, requires adequate surgical treatment. Its surgical correction involves rebuilding the muscleaponeurotic acquired defect, fixation of polypropylene mesh, which may be supra-aponeurotic, as in this series, with less complexity and lower rates of complications and recurrences.

\title{
R E S U M O
}

\begin{abstract}
Objetivo: avaliar os resultados da herniorrafia incisional subcostal com uso de tela de polipropileno, quanto aos aspectos técnicos da reconstrução músculo-aponeurótica, da fixação rotineira de tela supra-aponeurótica e o seguimento por cinco anos. Métodos: Estudo retrospectivo no qual foram avaliados 24 pacientes submetidos à herniorrafias incisionais subcostais com uso da tela de polipropileno, sendo 15 pacientes (62,5\%) do sexo feminino, com faixa etária variando de 33 a 82 anos, e 79,1\% apresentavam comorbidades. Resultados: Complicações precoces: três casos de infecção de ferida operatória $(12,5 \%)$, três casos de seromas (12,5\%), um caso de hematoma (4,1\%); um caso de deiscência da ferida operatória (4,1\%). Complicações tardias, houve um caso de recidiva herniária (4,1\%), atribuído à falha técnica na fixação da tela e um caso de dor crônica (4,1\%). Não houve nenhum caso de exposição ou rejeição da tela. Conclusão: A hérnia incisional subcostal, embora pouco prevalente, requer tratamento cirúrgico adequado. Sua correção cirúrgica implica em reconstrução músculo-aponeurótica do defeito, seguido de fixação de tela de polipropileno supra-aponeurótica, com menor complexidade e baixos índices de complicações e recidivas.
\end{abstract}

Descritores: Hérnia. Hérnia incisional. Procedimentos cirúrgicos operatórios. Polipropilenos. Avaliação de resultados (cuidados de saúde).

\section{REFERENCES}

1. Berg AA. III. Surgical treatment of cholelithiasis: a report of the operations for cholelithiasis, in the Service of Dr. A. G. Gerster, at Mount Sinai Hospital, during the five years, 1898-1902. Ann Surg. 1903;38(3):343-58.

2. Hughes K, Selim NM. The lateral paramedian: revisiting a forgotten incision. Am Surg. 2009;75(4):321-3.

3. Burger JW, van't Riet M, Jeekel J. Abdominal incisions: techniques and postoperative complications. Scand J Surg. 2002;91(4):31521.

4. Chute R, Baron JA Jr, Olsson CA. The transverse upper abdominal "chevron" incision in urological surgery. Trans Am Assoc Genitourin Surg. 1967;59:14-7.

5. Donataccio M, Genco B, Donataccio D. Right subcostal incision in liver transplantation: prospective study of feasibility. Transplant Proc. 2006;38(4):1109-10.

6. Piazzese $E$, Montalti $R$, Beltempo $P$, Bertelli $R$, Puviani $L$, Pacilè $V$, et al. Incidence, predisposing factors, and results of surgical treatment of incisional hernia after orthotopic liver transplantation. Transplant Proc. 2004;36(10):3097-8.

7. Piardi T, Audet M, Panaro F, Gheza F, Cag M, Portolani N, et al. Incisional hernia repair after liver transplantation: role of the mesh. Transplant Proc. 2010;42(4):1244-7.

8. Gianchandani R, Moneva E, Marrero P, Alonso M, Palacios MJ, Del Pino JM, et al. Feasibility and effectiveness of laparoscopic incisional hernia repair after liver transplantation. Transplant Proc. 2011;43(3):742-4.

9. Moreno-Egea A, Cartagena J, Vicente JP, Carrillo A, Aguayo JL. Laparoscopic incisional hernia repair as a day surgery procedure: audit of 127 consecutive cases in a university hospital. Surg Laparosc Endosc Percutan Tech. 2008;18(3):267-71.

10. Khambaty F, Brody F, Vaziri K, Edwards C. Laparoscopic versus single-incision cholecystectomy. World J Surg. 2011;35(5):967-72.
11. Ros A, Gustafsson L, Krook H, Nordgren CE, Thorell A, Wallin G, et al. Laparoscopic cholecystectomy versus mini-laparotomy cholecystectomy: a prospective, randomized, single-blind study. Ann Surg. 2001;234(6):741-9.

12. Israelsson LA, Smedberg S, Montgomery A, Nordin P, Spangen L. Incisional hernia repair in Sweden 2002. Hernia. 2006;10(3):25861

13. Halm JA, Lip H, Schmitz PI, Jeekel J. Incisional hernia after upper abdominal surgery: a randomised controlled trial of midline versus transverse incision. Hernia. 2009;13(3):275-80.

14. Lima JM. Tratamento cirúrgico das hernias incisionais: experiência pessoal usando a malha de polipropileno monofilamentar-márlex. Rev Col Bras Cir. 2002;29(2):78-82

15. Blomstedt B, Welin-Berger T. Incisional hernias. A comparison between midline, oblique and transrectal incisions. Acta Chir Scand. 1972;138(3):275-8

16. Peres MAO, Nieri TM, Barcelos Neto HS, Andreollo NA. A técnica de Lichtenstein nas hernias inguinais primárias e recidivas - cirurgia ambulatorial em hospital universitário. $A B C D$, arq bras cir dig. 2007;20(4):221-4.

17. Utrabo CAL, Czeczko NG, Busato CR, Montemor-Netto MR, Malafaia O, Dietz UA. Comparative study between polypropylene and polypropylene/poliglecaprone meshes used in the correction of abdominal wall defect in rats. Acta Cir Bras. 2012;27(4):3005 .

18. Moreno-Egea A, Guzmán P, Morales G, Carrillo A, Aguayo JL. Tratamineto de la eventración no medial: experiencia de una unidad de pared abdominal y revisión de la literatura. Cir Esp. 2007;81(6):330-4.

19. Burger JW, Luijendijk RW, Hop WC, Halm JA, Verdaasdonk EG, Jeekel J. Long-term follow-up of randomized controlled trial of suture versus mesh repair of incisional hernia. Ann Surg. 2004;240(4):578-83; discussion 583-5. 
Received on 19/11/2012

Accepted for publication 15/01/2013

Conflict of interest: none.

Source of funding: none.

\section{How to cite this article:}

Peres MAO, Aguiar HR, Andreollo NA. Surgical treatment of subcostal

incisional hernia with polypropylene mesh - analysis of late results. Rev
Col Bras Cir. [periódico na Internet] 2014;41(2). Disponível em URL: http://www.scielo.br/rcbc

Address for correspondence:

Marco Antonio de Oliveira Peres

Email: marcoperes@terra.com.br 